\title{
Command-And-Control or Taxation? The Cases of Water Regulation in California and Denmark
}

\author{
Christina Oh \\ Communications Manager of Worldwide Public Affairs \\ The Walt Disney Company, MA International Studies Aarhus University, Denmark \\ E-mail: oh.christina@gmail.com
}

Gert Tinggaard Svendsen

Professor, Ph.D., Department of Political Science and Government

Aarhus University, Denmark

E-mail: gts@ps.au.dk

Received: August 19, 2015 Accepted: September 5, 2015

doi:10.5296/emsd.v4i2.8358 URL: http://dx.doi.org/10.5296/emsd.v4i2.8358

\begin{abstract}
California and Denmark are both facing water scarcity issues as demand has increased and supply has decreased over the years. In order to solve this problem these two actors have chosen very different ways of dealing with sustaining an adequate amount of domestic water supply. California has chosen an ineffective command-and-control (CAC) tool, whereas Denmark has chosen the effective tool of taxation. One main explanation for this variation in policy choice is the variation in institutional setups, namely the corporatist route in Denmark versus the pluralistic route in California.
\end{abstract}

Keywords: California, Denmark, Command-and-control, Taxation, Pluralism, Water regulation.

Acknowledgements: We thank two anonymous reviewers for helpful comments.

"Nothing is more useful than water: but it will purchase scarcely anything; scarcely anything can be had in exchange for it. A diamond, on the contrary, has scarcely any use-value; but a very great quantity of other goods may frequently be had in exchange for it." Adam Smith (1991 [1776]). 


\section{Introduction}

A puzzling observation is that different countries use different instruments to regulate the use of natural resources such as water resources. In many regions of the world water demand has begun to outstrip available supplies. Both population growth and higher standards of living lead to greater per capita water consumption, making it increasingly difficult to balance supply and demand. Furthermore, climate change threatens the existing water supply, and it is predicted that the future will see an increased frequency of periods of drought (Collins et al., 2009; EUREAU, 2008). California is currently experiencing the most severe drought in a millennium due to low rainfall and record-high temperatures (Los Angeles Times, 2014).

California and Denmark are both progressive actors in the environmental political domain and are currently pressed with such water management issues. However, their governments have chosen and continue to choose very different policy routes for managing their domestic water supply. Why is it that individuals in Denmark use approximately 119 liters of water per day at home, whereas California residents use more than three times that amount, namely 378 liters (100 gallons) per day? What accounts for this significant difference in residential water use?

Does the fact that a Copenhagen resident pays approximately USD 7.71 per cubic meter of water explain the difference? In 2009 this was one of the highest water prices in the world (OECD, 2007 in Gleick, 2009, pp. 313-9). The total price of water has increased by 32 percent between 1996 and 2006. The current rate of the tax is DKK 5 per cubic meter of tap water, whereas the sewage tax of the water is around DKK 30 (Andersen, 2010). Danish policymakers have responded to the water scarcity and water stress and chosen taxation as their main instrument for providing the citizens with the collective good of water.

Californian policymakers have so far used command-and-control (CAC) regulations as the main instrument in governing the state's water. Currently Californian residents pay an average of 2 USD per cubic meter of potable water. This extremely low price (relative to prices in the rest of the Western developed world) does not provide much incentive for consumers to decrease their consumption. Also, this pricing, in many cases, does not cover all the costs of the agencies providing the water. Instead, California governments have implemented measures such as restricting lawn watering to twice a week (Gleick, 2009).

Although water is abundantly found on Earth, fresh water is a scarce resource. Only 2.5 percent of the total volume of water on Earth is fresh water. Of this fresh water less than 1 percent is available for human consumption (Tietenberg, 2007, p. 164). Water supplies come from two different types of sources: surface water and groundwater. Surface water is the fresh water found in rivers, lakes, and reservoirs that collect and flow on the Earth's surface, whereas groundwater collects in layers of underground rock. Groundwater makes up 90 percent of the Earth's available fresh water, and only 2.5 percent of this is renewable (ibid., p. 164). Thus, the importance of the Earth's fresh water resources and how water scarcity problems can arise is evident. 


\section{Macrothink}

The differences in environmental policies across borders have been extensively discussed in the literature. Andersen (1994a) has conducted a 1970-1990 comparative study of the water policies of Denmark, France, Germany, and the Netherlands in order to examine how green taxes have worked in practice. He has tested the effectiveness of economic instruments and shows how green taxes have made pollution prevention pay. Daugbjerg and Svendsen's (2001; 2003) research examines the political context of environmental policies in order to show how a 'small group' (industry) was able to lobby and exert influence to lower $\mathrm{CO} 2$ taxes, thus leaving the 'big group' (consumers) with higher taxes. Their research shows how taxes become differentiated and emphasizes that reimbursement schemes are necessary, either through earmarks for environmental subsidies or other tax reductions directed at the industry. Green taxation can be used with tax schemes for each branch of industry. Lundqvist, for example, has studied air, Andersen has studied water, and Daugbjerg and Svendsen have researched $\mathrm{CO} 2$; nevertheless, all of their work examines how environmental public policy can become effective and successful.

Daugbjerg and Svendsen (2003, p. 76) explain that the literature on green taxation is written mostly by economists who "attempt to develop environmental policy instruments that are economically efficient, ignoring the reality of political friction." This literature, however, should be much more multidisciplinary, combining different viewpoints in order to avoid 'blackboard economics'. Although green taxation can seem infeasible in the US and California, Tietenberg (2007, p. 181) emphasizes that increases in for example water prices can be politically feasible if done in the right way. Local politicians must be willing to take risks, and the local residents must be aware of and convinced that 'a real problem exists'. Furthermore, the burden of this increase should be distributed in such a way that no group is solely responsible or bears too large a burden. It seems that when residents are faced with drought and there is consumer support and awareness, major price changes are possible (ibid.).

In particular, Andersen (1994a, p. 53) poses the question: "Why have some countries been relatively more successful than others in the pursuit of environmental policy?" This paper contributes to the literature by taking that question into a more specific context, examining what causes the lower per capita water use in Denmark and the different policy-making styles in California and Denmark, respectively. Thus, the research question is the empirical puzzle of why California has chosen a CAC tool, whereas Denmark has chosen taxation to regulate the use of water.

We answer this main question in the following way. First, section 2 gives the theoretical framework for the tools of taxation and CAC based on environmental economics. Next, Section 3 argues that a main reason for the variation in policy choice is that Denmark pursues the route of corporatism, whereas California pursues a pluralistic one. Finally, Section 4 concludes the article.

\section{Taxation versus CAC}

From the toolbox of economic and non-economic instruments, we now focus on taxation and $\mathrm{CAC}$ in the following as the two predominant tools in Danish and Californian water 


\section{Macrothink

management policies.

\subsection{Taxation}

The first proposal of environmental taxation can be dated back to the earliest period of environmental policy and came from British economist Arthur Cecil Pigou (1887-1959). As he reflected on air pollution, especially looking at the London smog, he found that "pollution imposed uncovered costs on third parties which were not included in ordinary market transactions" (Andersen, 1994b, p. 2) and thus proposed to tax pollution with an externality tax. This tax would then internalize the damages caused by pollution. In short, Pigou's idea was to curb pollution by imposing a tax on it. At the time, the 1920s, Pigou's idea of an externality tax was a "rather academic approach to the control of pollution" and "did not gain any practical significance" (ibid.). However, in the 1970s the concept of Pigouvian taxes stated to gain popularity and experienced a revival as more and more countries started to apply economic instruments in practice. The idea of using taxes in environmental policy and broader welfare economic theories was thus pioneered by Pigou, and it remains important in today's policy-making. Figure 1 shows how a simple, ideal Pigouvian tax works.

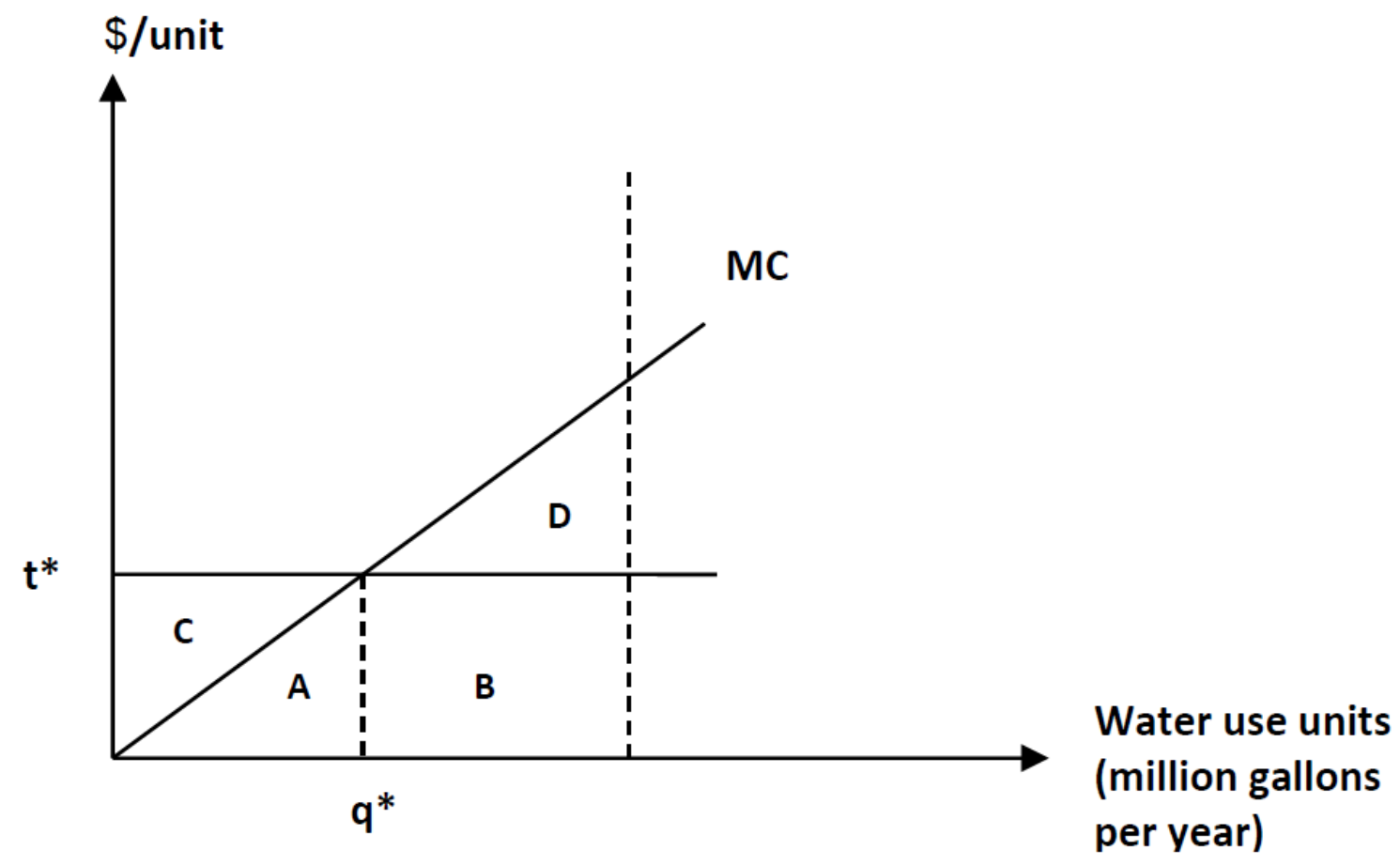

Figure 1. Ideal Pigouvian Tax

Figure 1 shows that when taxing the use of water by the tax $t^{*}$ per unit, $q^{*}$ will be consumed, because it is cheaper not to use water until that point than to pay the tax. By reducing water use, a farm, for example, saves area $C$ from not paying the tax. After $q^{*}$ it is cheaper to pay the water tax for each of the units the farm continues to use. Therefore, the farm saves area $D$ from not continuing to reduce water units on its own. It is now economically rational to change strategy and pay the tax which in total amounts to area $B$. The Pigou tax means that the farms bear the total costs of reducing water consumption (area $A$ ) and tax payment for 
consumed units (area $B$ ).

\subsection{Command-and-Control}

CAC regulations set standards, monitor, and enforce. They are traditionally the most common way for policy-makers to regulate the environment. The government simply specifies what is required and makes it an offense to fail to comply with this requirement (Hodge, 1995, p. 88). CAC regulations can take various forms. It can be an environmental quality standard that must be achieved (e.g. the concentration of a particular chemical in a body of water), a specific amount of permitted emissions (e.g. the noise level from an airport), or a particular action that must or must not be taken (e.g. a ban on a certain chemical) (ibid.).

Regulations are generally easy to introduce and administer. However, to make CAC regulations cost-effective, the "amount of information needed required by the regulatory authority is substantial," since the regulators "need to work out for themselves details of the way in which and the extent to which individual firms should act" (Hodge, 1995, p. 89). Governments rarely have such detailed information, thus forcing regulators to introduce these regulations without this information. Consequently, at least five main economic reasons exist for using taxation rather than CAC.

First, taxation brings the costs of affecting the environment (externalities) into the prices of the goods and services produced by economic activity. These are called externalities as they are side effects of the economic activity and their costs are not part of the prices paid by the producers or consumers directly involved (European Environment Agency, 2006). When externalities are not included in product and service prices, distortions in the market are created by encouraging activities that are costly to society, even if the private benefits are substantial (e.g. the full costs of using a car are external to the car driver and not fully included in the price of the car). Green taxes try to bring these external costs into the prices, so that the social and private costs are brought closer together (15) and signal the economic charges needed for conservation.

Second, green taxes provide incentives for deterring actions that damage the environment. In addition to using tax to internalize external environmental costs, taxation can be used to encourage changes in behavior. The tax gives the people affected an incentive to avoid the tax or pay less tax by using (e.g. water) or generating less (e.g. CO2 emissions) of the substance being taxed. However, since price is only one of the factors that determine economic behavior, the success of the tax in changing behavior depends on the market (ibid.). If there is an information gap and consumers do not understand the reason for this tax, it may fail to change their behavior. The success of the tax depends on its elasticity. We can, for example, talk about an inelastic demand, where a price change fails to change certain behavior. In those cases the tax can be coupled with other instruments as part of a policy package (ibid.). Stavins and Whitehead (1997, p. 105) explain how properly designed and implemented taxes provide incentives for individuals to "act in ways that further not only their own financial 
goals but also environmental aims." In contrast, CAC regulations "force everyone to implement the same pollution control strategies, regardless of the relative costs to them of this burden" (ibid., p. 106). With this type of regulation there is little or no financial incentive to "do better than the law requires" (ibid.), leading to drags in productivity and complaints about regulatory inefficiency.

Third, green taxes can also encourage innovation and the development of new technology. If the prices of a substance like water are increased through green taxes, people may be encouraged to find new ways of meeting needs, thus leading to new technologies, processes, and products (European Environment Agency, 2006). For example, faced with increased water prices consumers have developed new technologies such as rainwater harvesting (RWH). RWH systems collect rainwater and then use it to water gardens or, in more advanced cases, for non-potable uses such as toilets or washing machines. Furthermore, greywater systems are being developed, trying to make the most use of the water people have. For example, instead of sending the water used for washing hands straight down the sewer, it (called greywater) is transferred to the toilet, allowing the water to be used to its maximum.

Fourth, the revenue gained by taxes can also be used to reduce other taxes (e.g. labor taxes) or subsidize consumers conducting more environmentally safe activities, thus providing a second incentive for environmental improvement (ibid.). In general, taxes on labor, capital, and savings are more costly in terms of economic welfare than environmental taxes (ibid.). Thus, shifting the tax burden from those activities to environmental taxation can reduce market distortions and increase economic efficiency and welfare. This is the so-called 'double dividend', implying both environmental and fiscal effects following green taxation (Svendsen, 2013).

Fifth, taxes entail less administration and a "scaled down role for the agency by shifting decision making from the bureaucracy to the private sector," and thus bureaucrats may oppose taxes to "prevent their expertise from becoming obsolete" (Stavins, 2003, p. 14). In this way, taxes offer many advantages over CAC regulations, including operational simplicity and reduced administrative costs (Zetland, 2009).

However, environmental taxes can have negative effects on wealth redistribution. If low-income groups are forced to pay the same environmental taxes, a higher proportion of their income is used to pay for the tax, thus affecting low-income groups in a disproportional way. Some tax schemes have provisions to reduce the tax burden on low-income groups (European Environment Agency, 2006) For example, low-income groups may be given tax exemptions or tax free thresholds, or the tax revenues can be recycled back to them through compensations. In order to address the problematic effect of taxation on welfare distribution, it is important for policy-makers to analyze which groups in society are hit the hardest by taxes and which groups are not easily able to adapt to the impact of taxes and find solutions to ensure that low-income groups do not bear the burden.

\section{The Corporatist versus the Pluralist Route}

The political structure of countries - whether they practice democracy or autocracy - is an 
important factor in their environmental development. In the last century the world moved away from regimes that concentrate power in the hands of the one or few and toward democratic regimes that grant the people the right to rule by giving them the freedom of political participation. Scandinavian countries, including Denmark, exercise democracy by employing a high level of corporatism as the countries' interest groups are highly integrated in the decision-making process (Scruggs, 1999, p. 12). In contrast to pluralism, this high level of corporatism is closely connected with the establishment of democratic rights, as it allows Scandinavians to be represented by interest groups that have the freedom to organize, vote, and speak in a consensual, goal-oriented way.

In her research Scruggs (1999) concludes that corporatist institutions have a positive impact on environmental performance, as she controls for differences in economic structures, political institutions, and the mobilization of environmental interest groups. The arrangements of a corporatist society encourage public policy to include the ideas of interest groups. The availability of the corporatist route allows for example environmental interest groups to be included in the decision-making process and actually have a voice in policies. Corporatist societies are better at improving environmental policies due to their organized and consensual form of decision-making. This kind of institutional setup can also overcome decision-blocking problems, since corporatism has the ability to generously compensate losers (ibid., p. 2).

The corporatist political system in Denmark developed where "consensus had to be accomplished with the most important peak interest organizations before legislation was passed" (Andersen, 1999, p. 46). This meant that everything would be negotiated. Therefore, the Danish government has a significant corporatist element of environmental policy, and there is a strong Danish policy tradition for integrating affected interests into political and administrative decision-making arenas. Generally, the Danish policy-making style is "cooperative and consultative" (Munk Christiansen, 1996, p. 57). Interest organizations are involved in one way or another when decisions with specific consequences for limited groups are made. Organized interests are integrated in the policy-making process. The parties behind the 1973 Environmental Protection Act made "a great effort to obtain the consent of the industry" (ibid.). The new ministry worked on establishing good relations with different interest groups involved in environmental regulation.

The inclusion of interest organizations in Danish policy-making is government both politically and legally. Article 11 of the 1991 revised Danish Environmental Protection Act stipulates that the minister must "negotiate administrative rules with reference to the law with affected businesses and environmental organization, organizations representing counties and municipalities, and relevant state authorities" (Munk Christiansen, 1996, p. 57). In other words, the corporatist setup allows consumer interest groups to represent households, and these interest groups are expected to have a fair voice in shaping policy. As citizens hold these groups responsible and accountable for this policy, their opinions are also represented and heard in the political decision-making process, in spite of the fact that they belong to a 'large' group in the Olsonian sense (Olson 1965). Corporatism in this way compensates for collective action problems in large consumer/citizen groups by automatically incorporating 
all affected interests (Brandt and Svendsen, 2016). This could be the reason why Denmark (and other Scandinavian countries with corporatist political systems) is more likely to take overall societal interests into consideration and use taxation as the most cost-effective solution in for example water resource management.

\section{Conclusion}

The overall research question addressed the empirical puzzle of why California has chosen an ineffective CAV tool, whereas Denmark has chosen the cost-effective tool of taxation. We have argued that one reason why Californian policy-makers have not chosen taxation in their domestic water policy to decrease water consumption could be the fact that they operate in a pluralistic political system where the interests of small producer groups are not counteracted by large groups and overall societal interests. The lack of a corporatist route in California (in contrast to Denmark) makes it easier for small groups to dominate political decision-making. In a nutshell, Denmark's corporatist structure facilitates that effective policies, including water taxation, can work to the benefit of large groups and society.

In perspective, policy-makers in Denmark have successfully implemented taxation in their domestic water policy to provide an adequate amount of water for each citizen. This route has been very successful in Denmark, as studies show that per capita water use decreased over time when pricing went up. Danish citizens pay one of the highest water taxes in the world as a result of the government's use of demand-side management techniques, the objective of which has been to decrease the demand of water. In contrast, Californian per capita water use is today over three times the per capita water consumption in Denmark in a time when California's Governor Brown has declared a drought state of emergency.

\section{References}

Andersen, M. S. (1999). Governance by green taxes: implementing clean water policies in Europe 1970-1990. Environmental Economics and Policy Studies. 2, 39-27.

Andersen, M. S. (1994a). Governance by green taxes: Making pollution prevention pay. Manchester: Manchester University Press.

Andersen, M. S. (1994b). The use of economic instruments for environmental policy: A half-hearted affair. Department of Political Science, Aarhus University.

Brandt, U. S., \& Svendsen, G. T. (2016). The Politics of Persuasion: Should Lobbying be Regulated in the EU? Cheltenham, UK: Edward Elgar Publishing.

Collins, R., Kristensen, P., \& Thyssen, N. (2009). Water resources across Europe Confronting water scarcity and drought. European Environmental Agency, Copenhagen.

Danish Ministry of Taxation. (2010). 22 January (last update). Skattetryk for grønne afgifter. Available: http://www.skm.dk/tal_statistik/skatter_og_afgifter/675.html (April 20, 2010).

Daugbjerg, C., \& Svendsen, G. T. (2003). Designing green taxes in a political context: From optimal to feasible environmental regulation. Environmental Politics. 12(4), 76-95. 
Daugbjerg, C., \& Svendsen, G. T. (2001). Green taxation in question: Politics and economic efficiency in environmental regulation. Basingstoke: Palgrave.

Dinar, A. (2000). The political economy of water pricing reforms. World Bank, Oxford.

EUREAU (2008). EUREAU Statistics Overview on Water and Wastewater in Europe 2008. European Federation of National Associations of Water and Wastewater Services, Brussels.

European Environment Agency (2006). Using the market for cost-effective environmental policy: Market-based instruments in Europe. European Environment Agency.

Fukuyama, F. (2004). The Imperative of State-Building. Journal of Democracy. 15(2), 17-31.

Gidey, K. B. (2006a). Managing a Scarce Resource: DSM in Urban Water Governance. Master's edition. Department of Environmental, Social and Spatial Change, Roskilde University.

Gleick, P. (2010). City Brights. Available: http://www.sfgate.com/cgibin/blogs/gleick/index [2010, 1 May].

Gleick, P. (2009). The World's Water 2008-2009: The Biennial Report on Freshwater Resources. Pacific Institute for Studies in Development, Environment, and Security, Berkeley.

Gleick, P., Haasz, D., Henges-Jeck, C., Srinivasan, V., Wolff, G., Cushing, K., \& Mann, A. (2003). Waste Not, Want Not: The Potential for Urban Water Conservation in California. Pacific Institute for Studies in Development, Environment, and Security, Berkeley.

Grimble, R. J. (1999). Economic instruments for improving water use efficiency: Theory and practice. Agricultural Water Management. 40(1), 77-82.

Hodge, I. (1995). Environmental economics: Individual incentives and public choices. Basingstoke: MacMillan.

Ingebritsen, C. (2006). Small states in international relations. University of Washington Press; Seattle; Reykjavik: University of Iceland Press.

Klok, J., Larsen, A., Dahl, A., \& Hansen, K. (2006). Ecological Tax Reform in Denmark: History and social acceptability. Energy Policy. 34(8), 905-916.

Københavns Energy A/S (2010). Max 100. Available: http://www.ke.dk/portal/page/portal/Privat/Nyt\%20fra\%20Københavns\%20Energi\%20april\% 2020101/Max\%20100 (March 5, 2010).

Legislative Analyst's Office (2009). Water Rights: Issues and Perspectives. Legislative Analyst's Office.

Lindhjem, H., Nordic Council of Ministers, \& Nordic Council (2009). The use of economic instruments in Nordic environmental policy 2006-2009. Nordic Council of Ministers, 
Copenhagen.

Los Angeles Times (2014). Available:

http://www.latimes.com/local/lanow/la-me-ln-california-drought-worst-20141205-story.html_ (August 8, 2015).

Munk Christiansen, P. (1996). Governing the environment: Politics, policy, and organizations in the Nordic countries. Nordic Council of Ministers.

Niskanen, W. A. Jr. (1971). Bureaucracy and representative government. Atherton, Chicago: Aldine.

Olson, M. (1965). The logic of collective action. Cambridge: Harvard University Press.

Olson, M. (1982). The rise and decline of nations: Economic growth, stagflation, and social rigidities. New Haven: Yale University Press.

Pint, E. M. (1999). Household Responses to Increased Water Rates during the California Drought. Land Economics. 75(2), 246-266.

Reisner, M. (1993). Cadillac desert: The American West and its disappearing water. New York: Penguin Books.

Rogers, P., De Silva, R., \& Bhatia, R. (2002). Water is an economic good: How to use prices to promote equity, efficiency, and sustainability. Water Policy. 4(1), 1-17.

Schipper, L., \& Burton, I. (2009). The Earthscan reader on adaptation to climate change. London, Sterling: Earthscan.

Scruggs, L. (2001). Is there really a link between neo-corporatism and environmental performance? Updated evidence and new data for the 1980s and 1990s. British Journal of Political Science. 31(4), 686-692.

Scruggs, L. (1999). Institutions and environmental performance in seventeen western democracies. British Journal of Political Science. 29(1), 1-31.

Smith, A. (1991 [1776]). The Wealth of Nations. Everyman's Library. New York: Alfred A. Knopf.

Stavins, R. N. (2003). Market-based environmental policies: What can we learn from US experience (and related research)? Resources for the Future, Washington D.C.

Stavins, R., \& Whitehead, B. (1997). Market-Based Environmental Policies. In M. R. Chertow, \& D. C. Etsy (Eds.), Thinking Ecologically. The Next Generation of Environmental Policy (pp. 105-13). Yale University Press, Yale University.

Svendsen, G. T. (2013). From Brown to Green Economy: How to Promote Green Industries? Environmental Practice. 15. 72-78.

Tietenberg, T. (2007). Water. In T. Tietenberg, \& L. Lewis, Environmental Economics and 


\section{Macrothink \\ Environmental Management and Sustainable Development \\ ISSN 2164-7682 \\ 2015, Vol. 4, No. 2}

Policy (pp. 162-184). Prentice Hall.

Zetland, D. (2009). The end of abundance: How water bureaucrats created and destroyed the southern California oasis. Water Alternatives. 2(3), 350-69.

\section{Copyright Disclaimer}

Copyright for this article is retained by the author(s), with first publication rights granted to the journal.

This is an open-access article distributed under the terms and conditions of the Creative Commons Attribution license (http://creativecommons.org/licenses/by/3.0/). 